\title{
Augmentation of Dry Matter Production, Photosynthetic Enzymes, Yield Attributes and Quality Parameters of Sunflower through Seed Priming Effect of Gibberellic Acid-A Multifaceted Hormone
}

\author{
Nikhat Jafri ${ }^{*}$, Mohammad Mazid ${ }^{2}$ \\ ${ }^{1}$ Mascot Institute of Education, Meerut, India \\ ${ }^{2}$ Department of Agriculture, M. A. Jauhar University, Rampur, India \\ Email: ${ }^{*}$ Gitambotany008@gmail.com, biologydone@gmail.com
}

Received 20 March 2015; accepted 5 April 2015; published 10 April 2015

Copyright (C) 2015 by authors and OALib.

This work is licensed under the Creative Commons Attribution International License (CC BY).

http://creativecommons.org/licenses/by/4.0/

(c) (i) Open Access

\section{Abstract}

The aim of this experiment is to search best concentration of GA and appropriate duration (soaking hour) as well as to find out best interaction between best concentration and best soaking duration. Soaking the seeds with $10^{-5} \mathrm{M}$ GA for $8 \mathrm{~h}$ is best for growth and development of sunflower cv. PAC 3776. Surface sterilized seeds sunflowers (Helianthus annus L.) were soaked in 0, 10-7, $10^{-5}$ and $10^{-3} \mathrm{M}$ aqueous solution of gibberellic acid (GA) for $4,8,12$ and $16 \mathrm{~h}$ and sown in pots filled with $4 \mathrm{~kg}$ homogenous mixture of soil and farmyard manure in the ratio of 4:1. The plants were sampled at 50 and 70 days after sowing (DAS), for analysis of shoot and root dry weight, leaf area index (LAI), carbonic anhydrase activity (CA) and nitrate reductase (NR) activity, nitrogen (N), phosphorus (P) and potassium $(\mathrm{K})$ content at 50 and 70 DAS and seeds per head, seed yield, and harvest index, acid value, iodine value and saponification value at harvest (90 DAS). All parameters were found to be significantly enhanced by the GA seed priming effect, with maximum stimulation being noted following an $8 \mathrm{~h}$ soaking treatment with $\mathbf{1 0}^{-5} \mathrm{M} \mathrm{GA}$. Moreover, the most of the mentioned parameters were enhanced by $132.98 \%, 170.59 \%, 33.82 \%, 25.86 \%$ and $86.14 \%$ over the control at the 50 DAS except the $C A, N$, and $P$ found to be non-significant at this stage. $N$ content was found to be non-significant also at 70 DAS. Similarly, yield parameters were enhanced also by $123.49 \%, 44.76 \%, 41.38 \%, 111.76 \%$ and $1.64 \%$ respectively at harvest over control except iodine value. The objective of this experiment is to enhance the quality of sunflower constituents through application of best concentration and soaking time of GA.

\footnotetext{
"Corresponding author.
}

How to cite this paper: Jafri, N. and Mazid, M. (2015) Augmentation of Dry Matter Production, Photosynthetic Enzymes, Yield Attributes and Quality Parameters of Sunflower through Seed Priming Effect of Gibberellic Acid-A Multifaceted Hormone. Open Access Library Journal, 2: e1442. http://dx.doi.org/10.4236/oalib.1101442 


\title{
Keywords
}

\section{Acid Value, Dry Weight, Iodine Value, Productivity, Saponification Value}

\author{
Subject Areas: Metabolic Sciences, Plant Science
}

\section{Introduction}

Sunflower (Helianthus annus L.) is one of the annual oil crops of India. It is highly desirable for its premium oil, to supplement our oil seeds production, and contributes about $24 \%$ of the domestic edible oil production. The oil contains high degree of polyunsaturated fatty acids and anticholestric properties [1]. The efforts have been made today to increase its productivity by adopting the scientific agro-practices and by overcoming the incomplete development of seeds. Majority of farmers in our country has marginal holdings of less than two hectares, a major problem to boost-up its productivity. Keeping in mind such a limitation on increasing its productivity, it is highly desirable to find out ways which can augment the yield of this valuable oil yielding crop.

To meet the challenges of the low production and local requirements, there is need for multipronged strategy. In this context, efforts in the form of launching national programmes and research projects have been made by governmental and non-governmental organizations. The considerable number of fertilizers is rendered unavailable to the plants due to many factors, including leaching, fixation, decomposition and volatilization. For example, up to $50 \%$ of the soil-applied N [2], about $70 \%$ of the soil-applied P [3] and more or less $60 \%$ of the total applied sulphur (S) [4]-[6] may be lost due to one or more of these reasons. As mentioned earlier, there is limitation on increasing the acreage for cultivation, it is, therefore, highly logical to innovate ways that can improve the sunflower productivity. In this regard, an approach could be to make plants utilize fully the available resources leading to maximum harvesting of solar energy and subsequently enhancing the active sites. To attain such goal, the use of plant growth regulators (PGRs) may play an important role as they are known to affect many facets of plant life, including photosynthetic rate $\left(P_{N}\right)$, N-fixation, water and mineral uptake, harvest index (HI) [7]. Gibberellins are a class of endogenous plant growth substances exert pleiotropic effects on developmental processes like leaf expansion, stem elongation, cell collation and cell differentiation by co-ordinating with other PGRs like auxin, cytokinin, salicylic acid and triacontanol etc., [8]-[11]. Moreover, application of GA improves, among other processes, absorption and use efficiency of nutrients [12] [13], activity of enzymes [14] [15], cell division, cell enlargement [16] [17], chlorophyll content [15], elongation of internode [18], membrane permeability [17] [19], $P_{N}$ [20], nucleic acid and protein synthesis [18] [21], and transport of photosynthates [22]-[24].

Keeping in mind, the importance of this valuable oil producing crop, a pot experiment was conducted to investigate the effects of seed soaking (seed priming) effects of GA on growth characters, photosynthesis, enzyme activities, nutrient contents and yield attributes as well as quality parameters of sunflower. Therefore, this present work done to study, keeping in mind the immerse prospect of the crop like to increase its productivity especially in relation to seed yield and oil quality. Thus, the major goals of this research work are to determine the well-known effectiveness of GA treatments in enhancing productivity and yield of sunflower in India.

\section{Materials and Methods}

\subsection{Soil Analysis}

Just before sowing a composite soil sample, collecting from each pot, was analyzed for the soil characteristics. The soil sample was analyzed in the soil Testing Laboratory, Government Agriculture Farm, Quarsi, Aligarh. The physico-chemical properties of soil are given Table 1 .

\subsection{Plant Materials, Growth Conditions and Experimental Design}

A pot experiment was conducted on sunflower (Helianthus annus L.) during the zaid (summer) season in a net house of the department of Botany, Aligarh Muslim University, Aligarh. It is situated at $27^{\circ} 52^{\prime} \mathrm{N}$ latitude, $78^{\circ}$. The aim of this experiment was to study the effect of four concentrations and four soaking durations of pre- 
Table 1. Physico-chemical characteristics of the soil mixture used for the experiment.

\begin{tabular}{cc}
\hline Texture & Sandy loam \\
\hline $\mathrm{pH}(1: 2)$ & 7.6 \\
Conductivity $(1.2) \mathrm{dS} / \mathrm{m}$ & 0.43 \\
Available N (kg/ha) & 190.43 \\
Available P (kg/ha) & 10.00 \\
Available K (kg/ha) & 209.00 \\
\hline
\end{tabular}

sowing seed treatment of GA on the performance of sunflower cv. PAC 3776. The sunflower variety cv. PAC 3776 is characterized by one of the fastest growing oil seed crop in India, more economic in nature, also used as a ornamental plant, low irrigation requirement, minimum fertilizer and manures need but give well responses, and adopted to most of the soil category of India. The seeds obtained from the Advanta India, Sikandarabad (A.P), were surface-sterilized by soaking in $0.01 \% \mathrm{HgCl}_{2}$ solution for $3 \mathrm{~min}$, washed thoroughly with distilled water and divided into sixteen sets. Seeds are soaked in distilled water containing $10^{-7}, 10^{-5}$ and $10^{-3} \mathrm{M}$ GA respectively, for $4 \mathrm{~h}, 8 \mathrm{~h}, 12 \mathrm{~h}$ and $16 \mathrm{~h}$. After soaking, the thoroughly washed seeds were planted (10 per pot) in earthen pots ( $25 \mathrm{~cm}$ diameter) filled with $4 \mathrm{~kg}$ homogenous mixture of soil and farmyard manure (FYM) in the ratio of 4:1. The pots were arranged in a factorial randomized design. Each pot was supplied with NPK at the rate of $40 \mathrm{~kg} \mathrm{~N}+60 \mathrm{~kg} \mathrm{P}+40 \mathrm{~kg} \mathrm{~K} / \mathrm{ha}$ at the time of sowing. A half dose of $\mathrm{N}$ was applied at 25 DAS and the remaining half dose was given at 50 DAS. After germination only four uniform seedlings were left in each pot. Each treatment was replicated four times. The performance of the crop was assessed with regard to dry weight of shoot and root per plant, LAI per plant, CA activity and NR activity NPK content, seeds per head, seed yield per plant, HI, acid value, iodine value and saponification value of oil at harvest.

\subsection{Determination of Growth Characteristics}

The shoot and root of each plant were dried in a hot air oven at $80^{\circ} \mathrm{C}$ for $24 \mathrm{~h}$ and their dry weight was obtained separately with the help of an electronic balance. LAI is the ratio of foliage area to ground area. It is determined by the following formula suggested by Watson [25].

$$
\text { LAI }=\frac{\text { Leaf area }}{\text { Ground area }}
$$

\subsection{Determination of Physiological and Biochemical Parameters}

The activity of CA (E.C.4.2.1.1) determined in fresh leaves collected randomly from each replicate. The enzyme carbonic anhydrase is responsible for the catalysis for the reversible hydration of carbon dioxide $\left(\mathrm{CO}_{2}\right)$ to give the bicarbonate $\left(\mathrm{HCO}_{3}^{-}\right)$. The activity of the enzyme was estimated by adopting the method [26]. The collected leaves were cut into the small pieces $\left(1 \mathrm{~cm}^{2}\right)$ at a temperature below $20^{\circ} \mathrm{C}$. After mixing them, $200 \mathrm{mg}$ leaf pieces were weighed and cut further into smaller pieces keeping them in $100 \mathrm{ml} 0.2 \mathrm{M}$ aqueous cysteine hydrochloride solution in a Petri-dish at $0^{\circ} \mathrm{C}$ to $4^{\circ} \mathrm{C}$ for $20 \mathrm{~min}$. The solution adhering on their surface was thin removed with the help of a blotting paper. This was followed by transfer immediately into a test tube having $4 \mathrm{ml}$ phosphate buffer of PH 6.8. To this, $4 \mathrm{ml} 0.2 \mathrm{M}$ sodium bicarbonate (in $0.2 \mathrm{M}$ sodium hydra-oxide solution) and $0.2 \mathrm{ml}$ of $0.002 \%$ bromothymol blue indicator were added. After shaking, the tubes were kept at $0^{\circ} \mathrm{C}-4^{\circ} \mathrm{C}$ for 20 min. $\mathrm{CO}_{2}$ liberated during catalytic action of the enzyme on sodium bicarbonate was estimated by titrating the reaction mixture against $0.05 \mathrm{~N}$ hydrochloric acid, using methyl red as an indicator. A control reaction mixture was also titrated against $0.05 \mathrm{~N}$ hydrochloric acid. The difference of the sample reading and blank reading was noted for further calculations of enzyme activity. The activity of the enzyme was calculated by the following formula:

$$
\frac{0.5 \times V \times N}{W \times T} \mathrm{mmol}\left(\mathrm{CO}_{2}\right) / \mathrm{mg}(\text { leaf fresh mass }) / \mathrm{min}
$$

where, 
$V=$ Difference in volume (ml) of $\mathrm{HCl}$ used in blank and test sample titration

$N=$ Normality of $\mathrm{HCl}$

$W=$ Fresh weight of tissue in $\mathrm{mg}$

$T=$ Duration of the catalytic action of the enzyme (min)

The enzyme, nitrate reductase (E.C.1.6.6.1-3) catalyses the reduction of nitrate $\left(\mathrm{NO}_{3}^{-}\right)$to nitrite $\left(\mathrm{NO}_{2}^{-}\right)$. The nitrate reductase activity in fresh leaves was estimated by the method [27]. The leaves were cut into small pieces $\left(1 \mathrm{~cm}^{2}\right)$. Two hundred $\mathrm{mg}$ of these chopped leaves were weighed and transferred into plastic vials. To each vial, $2.5 \mathrm{ml}$ phosphatic buffer of $\mathrm{pH} 7.5$ and $0.5 \mathrm{ml}$ of potassium nitrate solution were added followed by the addition of $2.5 \mathrm{ml}$ of $5 \%$ isopropanol. These vials were incubated in a BOD incubator for $2 \mathrm{~h}$ at $30^{\circ} \mathrm{C} \pm 2^{\circ} \mathrm{C}$ in the dark. $0.4 \mathrm{ml}$ of incubated mixture was taken into test tube to which $0.3 \mathrm{ml}$ each of sulphanilamide solution and NED$\mathrm{HCl}$ were added. The test tube was left for $20 \mathrm{~min}$ for maximum colure development. The mixture was diluted to $5 \mathrm{ml}$ by adding DDW. The OD was recorded at $540 \mathrm{~nm}$ using the spectrophotometer.

$\mathrm{N}, \mathrm{P}$ and potassium $(\mathrm{K})$ were estimated in dried powder of leaves obtained from each replicate. The sampled plants leaves were dried in an oven at $80^{\circ} \mathrm{C}$ for $24 \mathrm{~h}$. The dried leaves from each sample were finally powdered and then passed through a 72-mesh screen. For the estimation of these nutrients, the leaf powder was first digested according to the standard technique.100 mg oven dried powder of leaf material was transferred into a digestion tube to which $2 \mathrm{ml}$ sulphuric acid was added. The tube was then kept on a digestion assembly at $80^{\circ} \mathrm{C}$ for about $2 \mathrm{~h}$ to allow the complete reduction of $\mathrm{NO}_{3}$ present in the plant material by the organic matter itself. Initially, dense white fumes were given off and then the content of the tube turned black. After cooling the tube for about $15 \mathrm{~min}, 0.5 \mathrm{ml} 30 \%$ hydrogen peroxide $\left(\mathrm{H}_{2} \mathrm{O}_{2}\right)$ was added drop by drop and the tube was heated again till the colour of the solution changed from black to light yellow. The digestion tube cooled for $10 \mathrm{~min}$ and an additional amount ( 2 - 3 drops) of $30 \% \mathrm{H}_{2} \mathrm{O}_{2}$ was added followed by gentle heating for about 15 min to get a clear and colourless solution. At this stage, care was taken in the addition of $\mathrm{H}_{2} \mathrm{O}_{2}$ because its excess might oxidize ammonia in the absence of organic matter. The $\mathrm{H}_{2} \mathrm{O}_{2}$ digested material was diluted with DDW and transferred with three washings into a $100 \mathrm{ml}$ volumetric flask and finally the volume was made up to the mark with DDW. The details of methods employed for the estimation of $\mathrm{N}, \mathrm{P}$ and $\mathrm{K}$ are given below.

$\mathrm{N}$ was estimated according to the method [28]. A $10 \mathrm{ml} \mathrm{H}_{2} \mathrm{SO}_{4}-\mathrm{H}_{2} \mathrm{O}_{2}$ digested material was taken into a $50 \mathrm{ml}$ volumetric flask and the excess of the acid was neutralized by the addition of $2 \mathrm{ml} 2.5 \mathrm{~N}$ sodium hydroxide. $1 \mathrm{ml}$ $100 \%$ sodium silicate was added to prevent turbidity and finally, the volume was made up with DDW. Into a 10 $\mathrm{ml}$ graduated test tube, $5 \mathrm{ml}$ this solution was taken and $0.5 \mathrm{ml}$ Nessler's reagent was added. The content of the test tube were allowed to stand for 5 min for maximum colour developed. The solution was transferred into a calorimetric tube and OD was read at $525 \mathrm{~nm}$, using a blank on the spectrophotometer. N content was determined with the help of the standard curve and was expressed in terms of percentage on dry weight basis.

P content in the $\mathrm{H}_{2} \mathrm{O}_{2}$ digested material was estimated [29]. $5 \mathrm{ml} \mathrm{H}_{2} \mathrm{SO}_{4}-\mathrm{H}_{2} \mathrm{O}_{2}$ digested material was taken into a $10 \mathrm{ml}$ graduated test tube and $1 \mathrm{ml}$ molybdic acid was carefully added followed by the addition of $0.4 \mathrm{ml}$ 1-amino-2-naphthol-4-sulphonic acid. The colour of the solution turned blue. The final volume in the tubes was made up to $10 \mathrm{ml}$ with DDW. After mixing thoroughly, the contents of the tube were allowed to stand for $5 \mathrm{~min}$. They were then transferred into a calorimetric tube and OD was read at $620 \mathrm{~nm}$ on the spectrophotometer. A blank was run simultaneously for each determination. P content was computed with the help of the standard curve and was expressed in terms of percentage on dry weight basis. $\mathrm{K}$ was estimated flame photometrically. 10 $\mathrm{ml} \mathrm{H}_{2} \mathrm{SO}_{4}-\mathrm{H}_{2} \mathrm{O}_{2}$ digested material was taken into a vial and was run into a flame photometer (AIMIL "Fotoflame”) using the filter for K. A blank was run side by side. K content was computed with the help of a standard curve and was expressed in terms of percentage on dry weight basis.

\subsection{Determination of Yield and Quality Characteristics}

The number of seeds per head was determined by counting the number of seeds of four heads. The total seeds of four plants (four heads) were threshed, cleaned and allowed to dry in the sun for some time and their weight was obtained with the help of an electronic balance, with expressing their weight on per plant basis. The HI was computed by dividing the seed yield of a plant by the biological yield of the plant and expressed on per cent basis.

$$
\text { Harvest index }=\frac{\text { Seed yield }}{\text { Biologicsl yield }} \times 100
$$


The acid value of oil is the number of mg of potassium hydroxide $(\mathrm{KOH})$ used to neutralize free acids in one gram of oil (mg KOH/g oil). It was determined by the titration method [30].

$2 \mathrm{~g}$ oil was dissolved in $50 \mathrm{ml}$ solvent mixture of 95\% ethyl alcohol and diethyl ether (1:1) in a $250 \mathrm{ml}$ conical flask. Titration was carried out with $0.1 \mathrm{~N} \mathrm{KOH}$ using phenolphthalein as an indicator and the amount of $\mathrm{ml}$ " $a$ " of $0.1 \mathrm{~N} \mathrm{KOH}$ required was noted. The acid value was determined by the following formula.

$$
\text { Acid value }=\frac{a \times 0.00561 \times 1000}{W}
$$

where,

$a=\mathrm{ml}$ of $0.1 \mathrm{~N} \mathrm{KOH}$ used in titration

$W=$ weight of oil in $\mathrm{g}$

The iodine value of oil is the number of $\mathrm{g}$ of iodine absorbed by $100 \mathrm{~g}$ oil (g 1/100g oil). It was determined by using iodine monochloride method describe below [30].

$2 \mathrm{~g}$ oil was placed into a dry $250 \mathrm{~m} 1$ round bottom flask. $10 \mathrm{ml}$ carbon Iran chloride and $20 \mathrm{ml}$ iodine monochloride solution were added. The flask was stoppered and allowed to stand in a dark place for about $30 \mathrm{~mm}$. Thereafter, $15 \mathrm{ml}$ potassium iodide solution and $100 \mathrm{ml}$ DDW were poured into the flask with gentle shaking. Titration was carried out with $0.1 \mathrm{~N}$ sodium thiosulphate solutions, using starch solution as an indicator. The number of $\mathrm{ml}$ " $a$ " of sodium thiosulphate used was noted. For blank, similar operation was performed but without the oil, and the number of $\mathrm{ml}$ " $b$ " of $0.1 \mathrm{~N}$ sodium thiosulphate solution used was noted. Iodine value was calculated by the following formula:

$$
\text { Iodine value }=\frac{(b-a) \times 0.01269 \times 100}{W}
$$

where,

$a=$ number of $\mathrm{ml}$ of $0.1 \mathrm{~N}$ sodium thiosuiphate solution used for the sample

$b=$ number of $\mathrm{ml}$ of $0.1 \mathrm{~N}$ sodium thiosulphate solution used for the blank

$W=$ weight of oil in $g$

The saponification value of oil is the number of $\mathrm{mg}$ of $\mathrm{KOH}$ required to neutralize the fatty acids resulting from the complete hydrolysis of $1 \mathrm{~g}$ of oil (mg KOH/g oil). It was determined by titration method [30]. $2 \mathrm{~g}$ oil was taken into a $250 \mathrm{ml}$ conical flask to which $25 \mathrm{ml} 0.5 \mathrm{~N} \mathrm{KOH}$ solution was added. The flask was attached with a reflux condenser and heated on a water bath for about $1 \mathrm{~h}$ with frequent rotation of the contents of the flask. After cooling, $1 \mathrm{ml}$ phenolphthalein solution was added. The excess of alkali was titrated with $0.5 \mathrm{~N} \mathrm{HCl}$ and the number of $\mathrm{ml}$ " $a$ " was noted. For blank, the operation was repeated in the same manner omitting the oil, and the number of $\mathrm{ml}$ " $b$ " required was noted. Saponification value was calculated by following formula:

$$
\text { Saponification value }=\frac{(b-a) \times 0.02805 \times 1000}{W}
$$

where,

$a=$ number of $\mathrm{ml}$ of $0.5 \mathrm{~N} \mathrm{HC} 1$ used for the sample

$b=$ number of $\mathrm{ml}$ of $0.5 \mathrm{~N} \mathrm{HC1}$ used for the blank

$W=$ weight of oil in $g$

The data of the experiment were analysed statistically by adopting the analysis of variance technique [31]. For the "F" test, the error due to replicates was also determined. When "F" value was found to be significant at $5 \%$ level of probability, critical difference (CD) was calculated.

\section{Results and Discussion}

\subsection{Growth Characteristics}

Soaking treatment $10^{-5} \mathrm{M} \mathrm{GA}$, followed by $10^{-3} \mathrm{M} \mathrm{GA}$, gave the maximum value at both stages. Soaking with $10^{-5} \mathrm{M}$ GA gave $125.0 \%$ and $52.38 \%$ higher value than $0 \mathrm{M} \mathrm{GA}$ at 50 and 70 DAS respectively. The effect of soaking durations on shoot dry weight was not found significant at both stages. Interaction $10^{-5} \mathrm{M} \mathrm{GA} \times 8 \mathrm{~h}$ gave the maximum value at both stages. However, its effect was at par with that of $10^{-5} \mathrm{M} \mathrm{GA} \times 12 \mathrm{~h}, 10^{-4} \mathrm{M}$ $\mathrm{GA} \times 16$ hand $10^{-5} \mathrm{M} \mathrm{GA} \times 4 \mathrm{~h}$ at both stages and also with that of $10^{-3} \mathrm{M} \mathrm{GA} \times 8 \mathrm{~h}$ at 70 DAS. Interaction $10^{-5} \mathrm{M}$ GA $\times 8$ h gave $132.98 \%$ and $53.99 \%$ higher shoot dry weight than the lowest value giving interaction 0 
$\mathrm{M} \mathrm{GA} \times 4 \mathrm{~h}$ at 50 and 70 DAS respectively, Table 2 . Soaking treatment $10^{-5} \mathrm{M}$ GA gave the maximum value for root dry weight at 50 DAS, with its effect being followed by that of $10^{-3} \mathrm{M} \mathrm{GA}$. Soaking with $10^{-3} \mathrm{M} \mathrm{GA}$ gave $150.41 \%$ higher values than $0 \mathrm{M} \mathrm{GA}$ at this stage. However, soaking concentrations did not vary in their effect at 70 DAS, Table 3.

Table 2. Effect of concentrations (C) and soaking durations (h) of pre-sowing seed treatment of $\mathrm{GA}_{3}$ on shoot dry weight per plant (g) of sunflower at 50 and 70 DAS (mean of four replicates).

\begin{tabular}{|c|c|c|c|c|c|}
\hline \multirow{2}{*}{ Soaking durations (h) } & \multicolumn{4}{|c|}{ Soaking concentrations $\left(\mathbf{M ~ G A}_{3}\right)$} & \multirow{2}{*}{ Mean } \\
\hline & Water & $10^{-7}$ & $10^{-5}$ & $10^{-3}$ & \\
\hline \multicolumn{6}{|c|}{50 DAS } \\
\hline 4 & 0.94 & 1.01 & 2.13 & 1.85 & 1.48 \\
\hline 8 & 0.98 & 1.13 & 2.19 & 1.88 & 1.55 \\
\hline 12 & 0.97 & 1.06 & 2.17 & 1.87 & 1.52 \\
\hline 16 & 0.96 & 1.02 & 2.15 & 1.86 & 1.51 \\
\hline Mean & 0.96 & 1.05 & 2.16 & 1.86 & \\
\hline C.D. at $5 \%$ & & $C=0.09$ & $\mathrm{D}=\mathrm{NS}$ & $\mathrm{C} \times \mathrm{D}=0.17$ & \\
\hline \multicolumn{6}{|c|}{70 DAS } \\
\hline 4 & 3.13 & 3.83 & 4.78 & 4.29 & 4.01 \\
\hline 8 & 3.17 & 3.91 & 4.82 & 4.41 & 4.08 \\
\hline 12 & 3.17 & 3.89 & 4.81 & 4.35 & 4.06 \\
\hline 16 & 3.14 & 3.85 & 4.79 & 4.33 & 4.03 \\
\hline Mean & 3.15 & 3.87 & 4.80 & 4.34 & \\
\hline C.D. at $5 \%$ & & $C=0.23$ & $\mathrm{D}=\mathrm{NS}$ & $\mathrm{C} \times \mathrm{D}=0.46$ & \\
\hline
\end{tabular}

NS = Non-significant.

Table 3. Effect of concentrations (C) and soaking durations (h) of pre-sowing seed treatment of $\mathrm{GA}_{3}$ on root dry weight per plant (g) of sunflower at 50 and 70 DAS (mean of four replicates).

\begin{tabular}{|c|c|c|c|c|c|}
\hline \multirow{2}{*}{ Soaking durations (h) } & \multicolumn{4}{|c|}{ Soaking concentrations $\left(\mathbf{M ~ G A}_{3}\right)$} & \multirow{2}{*}{ Mean } \\
\hline & Water & $10^{-7}$ & $10^{-5}$ & $10^{-3}$ & \\
\hline \multicolumn{6}{|c|}{50 DAS } \\
\hline 4 & 0.119 & 0.140 & 0.295 & 0.260 & 0.203 \\
\hline 8 & 0.130 & 0.182 & 0.322 & 0.282 & 0.229 \\
\hline 12 & 0.125 & 0.158 & 0.314 & 0.274 & 0.217 \\
\hline 16 & 0.121 & 0.145 & 0.304 & 0.263 & 0.208 \\
\hline Mean & 0.123 & 0.156 & 0.308 & 0.269 & \\
\hline C.D. at $5 \%$ & & $C=0.013$ & $\mathrm{D}=0.013$ & $\mathrm{C} \times \mathrm{D}=0.208$ & \\
\hline \multicolumn{6}{|c|}{70 DAS } \\
\hline 4 & 1.14 & 1.16 & 1.19 & 1.17 & 1.16 \\
\hline 8 & 1.17 & 1.19 & 1.24 & 1.19 & 1.17 \\
\hline 12 & 1.16 & 1.18 & 1.21 & 1.18 & 1.22 \\
\hline 16 & 1.15 & 1.16 & 1.21 & 1.18 & 1.18 \\
\hline Mean & 1.17 & 1.20 & 1.18 & 1.18 & \\
\hline C.D. at $5 \%$ & & $C=N S$ & $\mathrm{D}=\mathrm{NS}$ & $\mathrm{C} \times \mathrm{D}=\mathrm{NS}$ & \\
\hline
\end{tabular}

NS = Non-significant. 
Soaking treatment $10^{-5} \mathrm{M}$ GA gave the maximum LAI at both 50 and 70 DAS. However, its effect was at par with that of $10^{-3} \mathrm{M} \mathrm{GA}$ and $10^{-7} \mathrm{M}$ GA at 50 DAS and only with that of $10^{-3} \mathrm{M} \mathrm{GA}$ at 70 DAS. Soaking with $10^{-5}$ M GA gave $9.46 \%$ and $11.14 \%$ higher LAI than $0 \mathrm{M} \mathrm{GA}$ at 50 and 70 DAS respectively. Soaking for $8 \mathrm{~h}$ proved best at both stages. Its effect was followed at 50 DAS but equalled at 70 DAS by that of $12 \mathrm{~h}$ soaking. Soaking for $8 \mathrm{~h}$ gave $19.81 \%$ and $11.35 \%$ higher LAI than $4 \mathrm{~h}$ soaking at 50 and 70 respectively. Interaction $10^{-5} \mathrm{M} \mathrm{GA} \times 8 \mathrm{~h}$ gave the maximum LAI at both 50 and 70 DAS. However, its effect was at par with that of $10^{-3} \mathrm{M} \mathrm{GA} \times 8 \mathrm{~h}, 10^{-7} \mathrm{M} \mathrm{GA} \times 8 \mathrm{~h}$, and $10^{-5} \mathrm{M} \mathrm{GA} \times 12 \mathrm{~h}$ at 50 DAS and also by $10^{-5} \mathrm{M} \mathrm{GA} \times 12 \mathrm{~h}, 10^{-3} \mathrm{M}$ $\mathrm{GA} \times 12 \mathrm{~h}$ and $10^{-7} \mathrm{M} \mathrm{GA} \times 12 \mathrm{~h}$ at 70 DAS. Interaction $10^{-5} \mathrm{GA} \times 8 \mathrm{~h}$ gave $33.82 \%$ and $22.94 \%$ higher leaf area index than the lowest value giving interaction $0 \mathrm{M} \mathrm{GA} \times 4 \mathrm{~h}$ at 50 and 70 DAS respectively, Table 4.

\subsection{Physiological and Bio-Chemical Parameters}

Soaking treatment of $10^{-5} \mathrm{M}$ GA gave the maximum value at both stages for CA activity. Its effect was at par at 50 DAS and followed at 70 DAS by that of $10^{-3} \mathrm{M}$ GA. Soaking with $10^{-5} \mathrm{M}$ GA gave $16.07 \%$ and $11.07 \%$ higher value than $0 \mathrm{M} \mathrm{GA}$ at 50 and 70 DAS respectively. Soaking for $8 \mathrm{~h}$ proved the best at both stages, however its effect was at par with that of $12 \mathrm{~h}$ soaking. Soaking for $8 \mathrm{~h}$ gave $21.68 \%$ and $33.71 \%$ higher value than 4 $\mathrm{h}$ soaking at 50 and $70 \mathrm{DAS}$ respectively. Interaction $10^{-5} \mathrm{M} \mathrm{GA} \times 8 \mathrm{~h}$ gave the maximum value for CA activity at 70 DAS, however its effect was at par with that of $10^{-3} \mathrm{M} \mathrm{GA} \times 8 \mathrm{~h}$. Interaction $10^{-5} \mathrm{M} \mathrm{GA} \times 8 \mathrm{~h}$ gave $44.88 \%$ higher value than the lowest value giving interaction $0 \mathrm{M} \mathrm{GA} \times 4 \mathrm{~h}$ at $70 \mathrm{DAS}$. Effect of interactions on this parameter was, however not significant at 50 DAS, Table 5. Soaking treatment of $10^{-5} \mathrm{M}$ GA gave the maximum value of NR activity at both stages, with its effect being followed by that of $10^{-3} \mathrm{M}$ GA. Soaking with $10^{-5} \mathrm{M}$ GA gave $11.68 \%$ and $16.70 \%$ higher value than $0 \mathrm{M} \mathrm{GA}$ at 50 and 70 DAS respectively. Soaking for $8 \mathrm{~h}$ proved the best at both stages, with its effect being followed by that of $12 \mathrm{~h}$ soaking. Soaking for $8 \mathrm{~h}$ gave $11.59 \%$ and $12.02 \%$ higher value than $4 \mathrm{~h}$ soaking at 50 and 70 DAS respectively. Interaction $10^{-5} \mathrm{M} \mathrm{GA} \times 8 \mathrm{~h}$ gave the maximum value at both stages. Its effect was followed by that of $10^{-3} \mathrm{M} \mathrm{GA} \times 8 \mathrm{~h}, 10^{-5} \mathrm{M} \mathrm{GA} \times 12 \mathrm{~h}$, $10^{-7} \mathrm{M} \mathrm{GA} \times 8 \mathrm{~h}$ and $10^{-5} \mathrm{M} \mathrm{GA} \times 16 \mathrm{~h}$ at 50 DAS. However, effect of $10^{-5} \mathrm{M} \mathrm{GA} \times 8 \mathrm{~h}$ was at par with that of $10^{-3} \mathrm{M} \mathrm{GA} \times 8 \mathrm{~h}$ at $70 \mathrm{DAS}$. Interaction $10^{-5} \mathrm{M}$ GA $\times 8$ h gave $25.86 \%$ and $28.78 \%$ higher value than the lowest value giving interaction $0 \mathrm{M} \mathrm{GA} \times 4 \mathrm{~h}$ at 50 and 70 DAS respectively, Table 6 .

Table 4. Effect of concentrations (C) and soaking durations (h) of pre-sowing seed treatment of $\mathrm{GA}_{3}$ on leaf area index (LAI) of sunflower at 50 and 70 DAS (mean of four replicates).

\begin{tabular}{|c|c|c|c|c|c|}
\hline \multirow{2}{*}{ Soaking durations (h) } & \multicolumn{4}{|c|}{ Soaking concentrations ( $\left(\mathrm{M} \mathrm{GA}_{3}\right.$ ) } & \multirow{2}{*}{ Mean } \\
\hline & Water & $10^{-7}$ & $10^{-5}$ & $10^{-3}$ & \\
\hline \multicolumn{6}{|c|}{50 DAS } \\
\hline 4 & 2.04 & 2.07 & 2.24 & 2.13 & 2.12 \\
\hline 8 & 2.30 & 2.52 & 2.73 & 2.62 & 2.54 \\
\hline 12 & 2.27 & 2.30 & 2.49 & 2.15 & 2.35 \\
\hline 16 & 2.25 & 2.26 & 2.25 & 2.32 & 2.23 \\
\hline \multicolumn{6}{|l|}{ Mean } \\
\hline C.D. at $5 \%$ & & $C=0.18$ & $\mathrm{D}=0.18$ & $\mathrm{C} \times \mathrm{D}=0.35$ & \\
\hline \multicolumn{6}{|c|}{70 DAS } \\
\hline 4 & 4.01 & 4.26 & 4.32 & 4.36 & 4.23 \\
\hline 8 & 4.36 & 4.72 & 4.93 & 4.84 & 4.71 \\
\hline 12 & 4.30 & 4.68 & 4.76 & 4.70 & 4.61 \\
\hline 16 & 4.21 & 4.45 & 4.75 & 4.58 & 4.49 \\
\hline Mean & 4.22 & 4.52 & 4.69 & 4.62 & \\
\hline C.D. at 5\% & & $C=0.14$ & $\mathrm{D}=0.14$ & $\mathrm{C} \times \mathrm{D}=0.27$ & \\
\hline
\end{tabular}


Table 5. Effect of concentrations (C) and soaking durations (h) of pre-sowing seed treatment of $\mathrm{GA}_{3}$ on carbonic anhydrase activity [n mol $\mathrm{CO}_{2} / \mathrm{kg}($ leaf FW)/s] of sunflower at 50 and 70 DAS (mean of four replicates).

\begin{tabular}{|c|c|c|c|c|c|}
\hline \multirow{2}{*}{ Soaking durations (h) } & \multicolumn{4}{|c|}{ Soaking concentrations ( $\mathbf{M ~ G A}_{3}$ ) } & \multirow{2}{*}{ Mean } \\
\hline & Water & $10^{-7}$ & $10^{-5}$ & $10^{-3}$ & \\
\hline \multicolumn{6}{|c|}{50 DAS } \\
\hline 4 & 2.07 & 2.28 & 2.36 & 2.34 & 2.26 \\
\hline 8 & 2.56 & 2.68 & 2.92 & 2.85 & 2.75 \\
\hline 12 & 2.18 & 2.53 & 2.65 & 2.58 & 2.49 \\
\hline 16 & 2.13 & 2.35 & 2.47 & 2.41 & 2.34 \\
\hline Mean & 2.24 & 2.46 & 2.60 & 2.55 & \\
\hline C.D. at $5 \%$ & & $C=0.069$ & $\mathrm{D}=0.069$ & $\mathrm{C} \times \mathrm{D}=\mathrm{NS}$ & \\
\hline \multicolumn{6}{|c|}{70 DAS } \\
\hline 4 & 2.54 & 2.62 & 2.75 & 2.65 & 2.64 \\
\hline 8 & 3.32 & 3.38 & 3.68 & 3.64 & 3.53 \\
\hline 12 & 3.27 & 3.34 & 3.51 & 3.40 & 3.38 \\
\hline 16 & 2.80 & 2.92 & 3.28 & 3.14 & 3.04 \\
\hline Mean & 2.98 & 3.09 & 3.31 & 3.21 & \\
\hline C.D. at $5 \%$ & & $C=0.057$ & $\mathrm{D}=0.057$ & $\mathrm{C} \times \mathrm{D}=0.115$ & \\
\hline
\end{tabular}

NS = Non-significant.

Table 6. Effect of concentrations (C) and soaking durations (h) of pre-sowing seed treatment of $\mathrm{GA}_{3}$ on nitrate reductase activity [n mol $\mathrm{NO}_{2}^{-} / \mathrm{g} /($ leaf $\mathrm{FW}$ )/h] of sunflower at 50 and 70 DAS (mean of four replicates).

\begin{tabular}{|c|c|c|c|c|c|}
\hline \multirow{2}{*}{ Soaking durations (h) } & \multicolumn{4}{|c|}{ Soaking concentrations ( $\mathbf{M ~ G A}_{3}$ ) } & \multirow{2}{*}{ Mean } \\
\hline & Water & $10^{-7}$ & $10^{-5}$ & $10^{-3}$ & \\
\hline \multicolumn{6}{|c|}{50 DAS } \\
\hline 4 & 245.34 & 255.91 & 272.83 & 266.49 & 260.14 \\
\hline 8 & 274.84 & 285.53 & 308.79 & 293.98 & 290.29 \\
\hline 12 & 260.15 & 268.61 & 287.64 & 281.30 & 274.43 \\
\hline 16 & 253.80 & 264.37 & 283.41 & 270.72 & 268.08 \\
\hline Mean & 258.03 & 268.60 & 288.17 & 278.12 & \\
\hline C.D. at $5 \%$ & & $C=5.71$ & $\mathrm{D}=5.71$ & $C \times D=11.41$ & \\
\hline \multicolumn{6}{|c|}{70 DAS } \\
\hline 4 & 293.98 & 315.14 & 348.98 & 325.72 & 320.96 \\
\hline 8 & 336.28 & 355.33 & 378.59 & 368.02 & 359.55 \\
\hline 12 & 310.91 & 329.94 & 363.79 & 346.86 & 337.88 \\
\hline 16 & 300.33 & 321.48 & 357.44 & 338.12 & 327.09 \\
\hline Mean & 310.38 & 330.47 & 362.20 & 344.68 & \\
\hline C.D. at $5 \%$ & & $C=6.64$ & $\mathrm{D}=6.64$ & $C \times D=13.27$ & \\
\hline
\end{tabular}


Soaking treatment of $10^{-3} \mathrm{M}$ GA gave the maximum for leaf $\mathrm{N}$ content at both 50 and 70 DAS. Its effect was followed by $10^{-5} \mathrm{M}$ GA at both stages. Soaking with $10^{-3} \mathrm{M}$ GA gave $5.67 \%$ and $12.80 \%$ higher value than $0 \mathrm{M}$ GA at 50 and 70 DAS respectively. Soaking for 8 h proved the best at both stages, however its effect was followed by that of $12 \mathrm{~h}$ soaking. Soaking for $8 \mathrm{~h}$ gave $13.98 \%$ and $10.76 \%$ higher value than $4 \mathrm{~h}$ soaking at 50 and 70 DAS respectively. Of interactions on this parameter was not found significant at both 50 and 70 DAS, Table 7. Soaking treatment of $10^{-3} \mathrm{M}$ GA gave the maximum value for leaf $P$ content at 70 DAS. Its effect was followed by that of $10^{-5} \mathrm{M}$ GA at this stage. Soaking with $10^{-3} \mathrm{M}$ GA gave $43.30 \%$ higher value than $0 \mathrm{M} \mathrm{GA}$ at 70 DAS. However, a non-significant effect of soaking treatments was noted at 50 DAS. Soaking for $8 \mathrm{~h}$ proved the best at 70 DAS. Its effect was followed by that of $12 \mathrm{~h}$ soaking at this stage. Soaking for $8 \mathrm{~h}$ gave 24.23\% higher value than $4 \mathrm{~h}$ soaking at 70 DAS. Duration treatments did not affect on this parameter at 50 DAS. Interaction $10^{-3} \mathrm{M} \mathrm{GA} \times 8 \mathrm{~h}$ gave the maximum value at $70 \mathrm{DAS}$; however its effect was at par with that of $10^{-5} \mathrm{M}$ $\mathrm{GA} \times 8 \mathrm{~h}$. Interaction $10^{-3} \mathrm{M} \mathrm{GA} \times 8 \mathrm{~h}$ gave $67.63 \%$ higher value than the lowest value giving interaction $0 \mathrm{GA}$ $\times 4 \mathrm{~h}$ at 70 DAS. Interaction effect did not vary at 50 DAS, Table 8 .

Soaking treatment of $10^{-3} \mathrm{M}$ GA gave the maximum for leaf $\mathrm{K}$ content at both 50 and 70 DAS. However, its effect was at par with that of $10^{-5} \mathrm{M}$ GA at both stages and also by $10^{-7} \mathrm{M}$ GA at 70 DAS. Soaking with $10^{-3} \mathrm{M}$ GA gave $32.48 \%$ and $32.79 \%$ higher value than $4 \mathrm{~h}$ soaking at 50 and 70 DAS respectively. Soaking for $8 \mathrm{~h}$ proved the best at both stages, with its effect being followed by that of $12 \mathrm{~h}$ soaking. Soaking for $8 \mathrm{~h}$ gave $45.38 \%$ and $44.35 \%$ higher value than $4 \mathrm{~h}$ soaking at 50 and 70 DAS respectively. Interaction $10^{-3} \mathrm{M} \mathrm{GA} \times 8 \mathrm{~h}$ gave the maximum value at both stages. However, its effect was at par with that of $10^{-5} \mathrm{M} \mathrm{GA} \times 8 \mathrm{~h}$ at both stages and also by $10^{-7} \mathrm{M} \mathrm{GA} \times 8 \mathrm{~h}$ at 70 DAS. Interaction $10^{-3} \mathrm{M} \mathrm{GA} \times 8$ h gave $86.14 \%$ and $85.71 \%$ higher value than the lowest value giving interaction $0 \mathrm{M} \mathrm{GA} \times 4 \mathrm{~h}$ at 50 and 70 DAS respectively, Table 9 .

\subsection{Yield Characteristics}

Soaking treatment $10^{-5} \mathrm{M} \mathrm{GA}$, followed by $10^{-5} \mathrm{M}$ GA, gave the maximum value of seed per head. Soaking with $10^{-5} \mathrm{M}$ GA gave $108.51 \%$ higher value than $0 \mathrm{M}$ GA. Soaking for $8 \mathrm{~h}$ proved the best. Its effect was fol-

Table 7. Effect of concentrations (C) and soaking durations (D) of pre-sowing seed treatment of $\mathrm{GA}_{3}$ on nitrogen content (\%) of sunflower at 50 and 70 DAS (mean of four replicates).

\begin{tabular}{|c|c|c|c|c|c|}
\hline \multirow{2}{*}{ Soaking durations (h)- } & \multicolumn{4}{|c|}{ Soaking concentrations ( $\left(\mathbf{M ~ G A}_{3}\right.$ ) } & \multirow{2}{*}{ Mean } \\
\hline & Water & $10^{-7}$ & $10^{-5}$ & $10^{-3}$ & \\
\hline \multicolumn{6}{|c|}{50 DAS } \\
\hline 4 & 2.28 & 2.40 & 2.57 & 2.63 & 2.47 \\
\hline 8 & 2.47 & 2.53 & 2.68 & 2.75 & 2.61 \\
\hline 12 & 2.36 & 2.49 & 2.64 & 2.72 & 2.55 \\
\hline 16 & 2.32 & 2.44 & 2.59 & 2.66 & 2.50 \\
\hline Mean & 2.36 & 2.47 & 2.62 & 2.69 & \\
\hline C.D. at $5 \%$ & & $C=0.040$ & $\mathrm{D}=0.040$ & $\mathrm{C} \times \mathrm{D}=\mathrm{NS}$ & \\
\hline \multicolumn{6}{|c|}{70 DAS } \\
\hline 4 & 2.37 & 2.44 & 2.57 & 2.65 & 2.51 \\
\hline 8 & 2.60 & 2.74 & 2.81 & 2.96 & 2.78 \\
\hline 12 & 2.57 & 2.66 & 2.77 & 2.89 & 2.72 \\
\hline 16 & 2.46 & 2.59 & 2.68 & 2.78 & 2.63 \\
\hline Mean & 2.50 & 2.61 & 2.71 & 2.82 & \\
\hline C.D. at $5 \%$ & & $C=0.049$ & $\mathrm{D}=0.049$ & $\mathrm{C} \times \mathrm{D}=\mathrm{NS}$ & \\
\hline
\end{tabular}

NS = Non-significant. 
Table 8. Effect of concentrations (C) and soaking durations (h) of pre-sowing seed treatment of $\mathrm{GA}_{3}$ on leaf phosphorus content (\%) of sunflower at 50 and 70 DAS (mean of four replicates).

\begin{tabular}{|c|c|c|c|c|c|}
\hline \multirow{2}{*}{ Soaking durations (h) } & \multicolumn{4}{|c|}{ Soaking concentrations $\left(\mathbf{M ~ G A}_{3}\right)$} & \multirow{2}{*}{ Mean } \\
\hline & Water & $10^{-7}$ & $10^{-5}$ & $10^{-3}$ & \\
\hline \multicolumn{6}{|c|}{50 DAS } \\
\hline 4 & 0.240 & 0.288 & 0.360 & 0.375 & 0.315 \\
\hline 8 & 0.310 & 0.345 & 0.387 & 0.393 & 0.358 \\
\hline 12 & 0.289 & 0.322 & 0.374 & 0.389 & 0.343 \\
\hline 16 & 0.264 & 0.315 & 0.365 & 0.382 & 0.331 \\
\hline Mean & 0.275 & 0.317 & 0.371 & 0.384 & \\
\hline C.D. at $5 \%$ & & $\mathrm{C}=\mathrm{NS}$ & $\mathrm{D}=\mathrm{NS}$ & $\mathrm{C} \times \mathrm{D}=\mathrm{NS}$ & \\
\hline \multicolumn{6}{|c|}{70 DAS } \\
\hline 4 & 0.312 & 0.342 & 0.420 & 0.488 & 0.388 \\
\hline 8 & 0.402 & 0.487 & 0.514 & 0.523 & 0.482 \\
\hline 12 & 0.353 & 0.460 & 0.496 & 0.507 & 0.454 \\
\hline 16 & 0.340 & 0.448 & 0.476 & 0.492 & 0.439 \\
\hline Mean & 0.351 & 0.434 & 0.477 & 0.503 & \\
\hline C.D. at $5 \%$ & & $C=0.006$ & $\mathrm{D}=0.006$ & $\mathrm{C} \times \mathrm{D}=0.013$ & \\
\hline
\end{tabular}

Table 9. Effect of concentrations (C) and soaking durations (D) of pre-sowing seed treatment of $\mathrm{GA}_{3}$ on leaf potassium content (\%) of sunflower at 50 and 70 DAS (mean of four replicates).

\begin{tabular}{|c|c|c|c|c|c|}
\hline \multirow{2}{*}{ Soaking durations (h) } & \multicolumn{4}{|c|}{ Soaking concentrations $\left(\mathbf{M ~ G A}_{3}\right)$} & \multirow{2}{*}{ Mean } \\
\hline & Water & $10^{-7}$ & $10^{-5}$ & $10^{-3}$ & \\
\hline \multicolumn{6}{|c|}{50 DAS } \\
\hline 4 & 1.01 & 1.19 & 1.27 & 1.28 & 1.19 \\
\hline 8 & 1.58 & 1.69 & 1.76 & 1.88 & 1.73 \\
\hline 12 & 1.04 & 1.56 & 1.55 & 1.57 & 1.43 \\
\hline 16 & 1.03 & 1.29 & 1.31 & 1.48 & 1.28 \\
\hline Mean & 1.17 & 1.43 & 1.48 & 1.55 & \\
\hline C.D. at $5 \%$ & & $C=0.07$ & $\mathrm{D}=0.07$ & $\mathrm{C} \times \mathrm{D}=0.13$ & \\
\hline \multicolumn{6}{|c|}{70 DAS } \\
\hline 4 & 1.05 & 1.26 & 1.32 & 1.34 & 1.24 \\
\hline 8 & 1.63 & 1.76 & 1.83 & 1.95 & 1.79 \\
\hline 12 & 1.12 & 1.61 & 1.62 & 1.64 & 1.50 \\
\hline 16 & 1.07 & 1.35 & 1.36 & 1.56 & 1.34 \\
\hline Mean & 1.22 & 1.49 & 1.53 & 1.62 & \\
\hline C.D. at $5 \%$ & & $C=0.14$ & $\mathrm{D}=0.14$ & $\mathrm{C} \times \mathrm{D}=0.27$ & \\
\hline
\end{tabular}

lowed by that of $12 \mathrm{~h}$ soaking. Soaking for $8 \mathrm{~h}$ gave $5.32 \%$ higher value than $4 \mathrm{~h}$ soaking. Interaction $10^{-5} \mathrm{M}$ $\mathrm{GA} \times 8 \mathrm{~h}$ gave the maximum value, however its effect was at par with that of $10^{-5} \mathrm{M} \mathrm{GA} \times 12 \mathrm{~h}$ and $10^{-5} \mathrm{M} \mathrm{GA}$ $\times 16 \mathrm{~h}$. Interaction $10^{-5} \mathrm{M} \mathrm{GA} \times 8 \mathrm{~h}$ gave $123.49 \%$ higher value than the lowest value giving interaction $0 \mathrm{M}$ 
GA $\times 4$ h, Table 10. Soaking treatment $10^{-5} \mathrm{M}$ GA gave the maximum value of seed yield per plant. Its effect was followed by that of $10^{-3} \mathrm{M}$ GA. Soaking with $10^{-5} \mathrm{M}$ GA gave $42.2 \%$ higher value than $0 \mathrm{M}$ GA. The effect of soaking durations on seed yield was not found significant. Interaction of $10^{-5} \mathrm{M} \mathrm{GA} \times 8$ h gave the maximum value, however its effect was at par with that of $10^{-5} \mathrm{M} \mathrm{GA} \times 12 \mathrm{~h}, 10^{-5} \mathrm{M} \mathrm{GA} \times 16 \mathrm{~h}$ and $10^{-5} \mathrm{M} \mathrm{GA} \times 4 \mathrm{~h}$. Interaction $10^{-5} \mathrm{M} \mathrm{GA} \times 8$ h gave $44.76 \%$ higher value than the lowest value giving interaction $0 \mathrm{M} \mathrm{GA} \times 4 \mathrm{~h}$, Table 11. Soaking treatment $10^{-5} \mathrm{M}$ GA gave the maximum value of HI. Its effect was followed by that of $10^{-3}$ M GA. Soaking with $10^{-5} \mathrm{M}$ GA gave $40.28 \%$ higher value than $0 \mathrm{M} \mathrm{GA}$. The effect of soaking durations was not found significant on this parameter. Interaction $10^{-5} \mathrm{M} \mathrm{GA} \times 8 \mathrm{~h}$ gave the maximum value, however its effect was at par with that of $10^{-3} \mathrm{M} \mathrm{GA} \times 12 \mathrm{~h}, 10^{-3} \mathrm{M} \mathrm{GA} \times 16 \mathrm{~h}, 10^{-3} \mathrm{M} \mathrm{GA} \times 4 \mathrm{~h}, 10^{-5} \mathrm{M} \mathrm{GA} \times 8 \mathrm{~h}, 10^{-5} \mathrm{M}$ $\mathrm{GA} \times 12 \mathrm{~h}, 10^{-5} \mathrm{M} \mathrm{GA} \times 16 \mathrm{~h}$ and $10^{-5} \mathrm{M} \mathrm{GA} \times 4 \mathrm{~h}$. Interaction $10^{-3} \mathrm{M} \mathrm{GA} \times 8 \mathrm{~h}$ gave $41.38 \%$ higher value than the lowest value giving interaction $0 \mathrm{M} \mathrm{GA} \times 4 \mathrm{~h}$, Table 12 .

Table 10. Effect of concentrations (C) and soaking durations (D) of pre-sowing seed treatment of $\mathrm{GA}_{3}$ on seeds per head of sunflower at harvest (mean of four replicates).

\begin{tabular}{|c|c|c|c|c|c|}
\hline \multirow{2}{*}{ Soaking durations (h) } & \multicolumn{4}{|c|}{ Soaking concentrations $\left(\mathbf{M ~ G A}_{3}\right.$ ) } & \multirow{2}{*}{ Mean } \\
\hline & Water & $10^{-7}$ & $10^{-5}$ & $10^{-3}$ & \\
\hline \multicolumn{6}{|c|}{50 DAS } \\
\hline 4 & 315.0 & 462.0 & 680.0 & 534.0 & 497.75 \\
\hline 8 & 350.0 & 492.0 & 704.0 & 551.0 & 524.25 \\
\hline 12 & 339.0 & 483.0 & 696.0 & 543.0 & 515.25 \\
\hline 16 & 324.0 & 470.0 & 689.0 & 538.0 & 505.25 \\
\hline Mean & 332.0 & 476.7 & 692.0 & 541.0 & \\
\hline C.D. at $5 \%$ & & $C=8.77$ & $\mathrm{D}=8.77$ & $C \times D=17.53$ & \\
\hline
\end{tabular}

Table 11. Effect of concentrations (C) and soaking durations (D) of pre-sowing seed treatment of GA 3 on seed yield per plant of sunflower at harvest (mean of four replicates).

\begin{tabular}{|c|c|c|c|c|c|}
\hline \multirow{2}{*}{ Soaking durations (h) } & \multicolumn{4}{|c|}{ Soaking concentrations ( $\mathbf{M ~ G A}_{3}$ ) } & \multirow{2}{*}{ Mean } \\
\hline & Water & $10^{-7}$ & $10^{-5}$ & $10^{-3}$ & \\
\hline \multicolumn{6}{|c|}{50 DAS } \\
\hline 4 & 19.57 & 22.15 & 28.03 & 25.49 & 23.81 \\
\hline 8 & 20.01 & 22.59 & 28.33 & 25.76 & 24.17 \\
\hline 12 & 19.93 & 22.47 & 28.29 & 25.64 & 24.08 \\
\hline 16 & 19.79 & 22.29 & 28.16 & 25.58 & 23.95 \\
\hline Mean & 19.83 & 22.38 & 28.20 & 25.62 & \\
\hline C.D. at 5\% & & $C=2.54$ & $\mathrm{D}=\mathrm{NS}$ & $\mathrm{C} \times \mathrm{D}=5.07$ & \\
\hline
\end{tabular}

Table 12. Effect of concentrations (C) and soaking durations (D) of pre-sowing seed treatment of GA $\mathrm{G}_{3}$ on harvest index (HI) of sunflower at harvest (mean of four replicates).

\begin{tabular}{|c|c|c|c|c|c|}
\hline \multirow{2}{*}{ Soaking durations (h) } & \multicolumn{4}{|c|}{ Soaking concentrations $\left(\mathbf{M ~ G A}_{3}\right)$} & \multirow{2}{*}{ Mean } \\
\hline & Water & $10^{-7}$ & $10^{-5}$ & $10^{-3}$ & \\
\hline \multicolumn{6}{|c|}{50 DAS } \\
\hline 4 & 33.18 & 36.98 & 46.74 & 42.55 & 39.86 \\
\hline 8 & 33.59 & 37.67 & 46.91 & 42.84 & 40.25 \\
\hline 12 & 33.46 & 37.48 & 46.90 & 42.65 & 40.12 \\
\hline 16 & 33.25 & 37.18 & 47.71 & 42.57 & 39.93 \\
\hline Mean & 33.37 & 37.33 & 46.71 & 42.65 & \\
\hline C.D. at $5 \%$ & & $\mathrm{C}=1.71$ & $\mathrm{D}=\mathrm{NS}$ & $\mathrm{C} \times \mathrm{D}=3.41$ & \\
\hline
\end{tabular}


Soaking treatment $10^{-5} \mathrm{M}$ GA gave the maximum response for acid value. Its effect was followed by that of $10^{-3} \mathrm{M} \mathrm{GA}$ and $10^{-7} \mathrm{M}$ GA. Soaking with $10^{-5} \mathrm{M}$ GA gave $72.88 \%$ higher value than $0 \mathrm{M} \mathrm{GA}$. Soaking for $8 \mathrm{~h}$ proved best, however its effect was at par with that of $12 \mathrm{~h}$ soaking. Soaking for $8 \mathrm{~h}$ gave $20.00 \%$ higher value than $4 \mathrm{~h}$ soaking. Interaction $10^{-5} \mathrm{M} \mathrm{GA} \times 8 \mathrm{~h}$ gave the maximum value. However, its effect was at par with that of $10^{-5} \mathrm{M} \mathrm{GA} \times 12 \mathrm{~h}, 10^{-5} \mathrm{M} \mathrm{GA} \times 16 \mathrm{~h}, 10^{-5} \mathrm{M} \mathrm{GA} \times 4 \mathrm{~h}, 10^{-3} \mathrm{M} \mathrm{GA} \times 8 \mathrm{~h}$ and $10^{-3} \mathrm{M} \mathrm{GA} \times 12 \mathrm{~h}$. Interaction $10^{-5} \mathrm{M} \mathrm{GA} \times 8 \mathrm{~h}$ gave $111.76 \%$ higher value than the lowest value giving interaction $0 \mathrm{M} \mathrm{GA} \times 4 \mathrm{~h}$, Table 13 . The effect of soaking concentrations and soaking durations as well as their interactions was not found significant on iodine value, Table 14. The effect of soaking concentrations was not found significant for saponification value. The effect of soaking durations was also not found significant on this parameter. Interaction $10^{-3} \mathrm{M} \mathrm{GA} \times$ $8 \mathrm{~h}$ gave the maximum value. However, its effect was at par with that of $10^{-3} \mathrm{M} \mathrm{GA} \times 12 \mathrm{~h}, 10^{-3} \mathrm{M} \mathrm{GA} \times 16 \mathrm{~h}$, $10^{-3} \mathrm{M} \mathrm{GA} \times 4 \mathrm{~h}, 10^{-5} \mathrm{M} \mathrm{GA} \times 8 \mathrm{~h}, 10^{-5} \mathrm{M} \mathrm{GA} \times 12 \mathrm{~h}$ and $10^{-5} \mathrm{M} \mathrm{GA} \times 16 \mathrm{~h}$. Interaction $10^{-3} \mathrm{M} \mathrm{GA} \times 8 \mathrm{~h}$ gave 1.64\% higher value than the lowest value giving interaction $0 \mathrm{M} \mathrm{GA} \times 4 \mathrm{~h}$, Table 15 .

Table 13. Effect of concentrations (C) and soaking durations (D) of pre-sowing seed treatment of $\mathrm{GA}_{3}$ on acid value of the oil of sunflower (mg KOH/g oil) at harvest (mean of four replicates).

\begin{tabular}{|c|c|c|c|c|c|}
\hline \multirow{2}{*}{ Soaking durations (h) } & \multicolumn{4}{|c|}{ Soaking concentrations (M GA $\mathbf{A}_{3}$ ) } & \multirow{2}{*}{ Mean } \\
\hline & Water & $10^{-7}$ & $10^{-5}$ & $10^{-3}$ & \\
\hline \multicolumn{6}{|c|}{50 DAS } \\
\hline 4 & 0.51 & 0.72 & 0.97 & 0.78 & 0.75 \\
\hline 8 & 0.69 & 0.87 & 1.08 & 0.97 & 0.90 \\
\hline 12 & 0.62 & 0.84 & 1.05 & 0.94 & 0.86 \\
\hline 16 & 0.55 & 0.76 & 0.99 & 0.85 & 0.79 \\
\hline Mean & 0.59 & 0.80 & 1.02 & 0.88 & \\
\hline C.D. at $5 \%$ & & $C=0.08$ & $\mathrm{D}=0.08$ & $\mathrm{C} \times \mathrm{D}=0.15$ & \\
\hline
\end{tabular}

Table 14. Effect of concentrations (C) and soaking durations (D) of pre-sowing seed treatment of $\mathrm{GA}_{3}$ on iodine value of the oil of sunflower (g l/100g) at harvest (mean of four replicates).

\begin{tabular}{|c|c|c|c|c|c|}
\hline \multirow{2}{*}{ Soaking durations (h) } & \multicolumn{4}{|c|}{ Soaking concentrations ( $\mathbf{M ~ G A}_{3}$ ) } & \multirow{2}{*}{ Mean } \\
\hline & Water & $10^{-7}$ & $10^{-5}$ & $10^{-3}$ & \\
\hline \multicolumn{6}{|c|}{50 DAS } \\
\hline 4 & 0.51 & 0.72 & 0.97 & 0.78 & 0.75 \\
\hline 8 & 0.69 & 0.87 & 1.08 & 0.97 & 0.90 \\
\hline 12 & 0.62 & 0.84 & 1.05 & 0.94 & 0.86 \\
\hline 16 & 0.55 & 0.76 & 0.99 & 0.85 & 0.79 \\
\hline Mean & 0.59 & 0.80 & 1.02 & 0.88 & \\
\hline C.D. at $5 \%$ & & $C=0.08$ & $\mathrm{D}=0.08$ & $\mathrm{C} \times \mathrm{D}=0.15$ & \\
\hline
\end{tabular}

Table 15. Effect of concentrations (C) and soaking durations (D) of pre-sowing seed treatment of GA $\mathrm{A}_{3}$ on saponification value of the oil of sunflower at harvest (mean of four replicates).

\begin{tabular}{|c|c|c|c|c|c|}
\hline \multirow{2}{*}{ Soaking durations (h) } & \multicolumn{4}{|c|}{ Soaking concentrations $\left.(\mathbf{M ~ G A})_{3}\right)$} & \multirow{2}{*}{ Mean } \\
\hline & Water & $10^{-7}$ & $10^{-5}$ & $10^{-3}$ & \\
\hline \multicolumn{6}{|c|}{50 DAS } \\
\hline 4 & 188.63 & 190.03 & 190.52 & 191.44 & 190.15 \\
\hline 8 & 189.33 & 190.45 & 190.74 & 191.72 & 190.56 \\
\hline 12 & 189.26 & 190.31 & 190.66 & 191.65 & 190.47 \\
\hline 16 & 189.19 & 190.17 & 190.59 & 191.58 & 190.38 \\
\hline Mean & 189.10 & 190.24 & 190.62 & 191.59 & \\
\hline C.D. at $5 \%$ & & $\mathrm{C}=\mathrm{NS}$ & $\mathrm{D}=\mathrm{NS}$ & $\mathrm{C} \times \mathrm{D}=1.17$ & \\
\hline
\end{tabular}


As is complete evident from the Tables 2-15, plants from the GA treated seeds showed significant enhancement over the control in all parameters studied. The genetic potential of the plants is realized to a great extent by a recognized group of phytohormone or PGR called GA, like all other phytohormones, this also involved or express their potential of regulation of physiological processes of plants by modification of transcription, translation and/or differential sensitivity of the tissues. The receptors for GA are found on the plasma membrane. The difference in performance of sunflower to various concentrations of GA with respect to different soaking periods could be ascribed to the variations caused in their genetic makeup. Maximum stimulation was noted because of $10^{-5} \mathrm{M}$ GA following $8 \mathrm{~h}$ pre-sowing soaking, in which case, the values of shoot and root dry weight and LAI were elevated by $132.98 \%, 170.59 \%$ and $33.82 \%$ respectively, over the control at the 50 DAS sampling stage. Similar enhancements of $25.86 \%$ and $86.14 \%$ for NR and $\mathrm{K}$ respectively at the same stage. Moreover, oil quality characteristics like acid value and saponification value were registered an increase of $111.76 \%$ and $1.64 \%$ respectively over the control, whereas seed yield was elevated by $44.76 \%$ following the hormone treatment at harvest.

The observed ameliorative effect of pre-sowing seed treatment with GA particularly at $10^{-5} \mathrm{M}$ GA over the control on shoot and root dry weight per plant and LAI of 50 and 70 DAS can be traced to its various roles in the plants. The observed increases in growth parameters can be primarily attributed to the optimization of cell wall extensibility. Huttly and Phillips [21], in their review article, suggested that wall extensibility is the principal responsible factor that control cell expansion which, in turn, may be considered a central detrimental causative agent for growth like activities. In fact, GA has been found to be correlated with increased activity of the enzyme xyloglyconendotrans-glycosylase, which catalyses the breaking and forming of bonds between xyloglycon residues, thus permitting a transient increase in cell wall extensibility, and inducing elongation and cell expansion, which is apparent herein as increased shoot and root dry weight and LAI, Tables 2-4. Increased LAI, in turn, provides increased opportunity for light harvesting, which ultimately manifests as more dry matter. This stance is also supported by the strong positive correlation obtained herein between LAI and dry matter $(r=0.984)$.

It is known that CA has an active role in photosynthesis, which is established by its presence in all photosynthesizing tissues, where it catalyzes the reversible hydration of $\mathrm{CO}_{2}$, thereby increasing its availability for Rubisco [32] [33]. GA is already known to have an enhancing effect on the efficiency of Rubisco [13] [34]. Nitrate reducing power of the plant is one of the important factors determining the growth. However, the processes of nitrate reduction is directly, indirectly dependent on the metabolic sensors and/or/signal transducers [35]. The level of enzyme, NR is dependent on a number of factors borned within/outside of the plants. In the present research study, leaves of plants from the GA-treated seeds were found to possess more CA activity than the control, Table 5. A probable cause may be some influence of GA on the de novo synthesis of GA, which involves translation/transcription [36] [37]. GA is in fact known to affect these processes and hence has some control over protein and enzyme synthesis [21] [33]. As such, GA was found to enhance the activity of CA and NR, most probably, by causing an enhancement in its relative concentration in the plant tissues. Enhancement in shoot and root dry weight and LAI were expectedly reflected from increased shoot and root length of treated plants because levels of treated plants possessed a greater surface area which caused presumably be due to cell division and cell-enlargement induced by application of GA [38]. It was further supported by findings of Sairam [39], where the hormonal treatment, increased leaf area. Similar results have also been obtained by a few workers [40]-[42] on pre-sowing seed treatment and on foliar application [43]-[46].

Moreover, the leaves of seed priming plants also exhibited a higher state of metabolic activity. It was evident by the elevated level for the $P_{N}$ (data not published) that might positively contribute to the enhanced LAI and plant dry mass production. The superior dry weight of the shoot and root of plant in response to GA treatment could be due to the cumulative effect of enhanced values of various growth parameters. The correlation studied also revealed that LAI has relationship with shoot and root dry weight with shoot length (data not published). Similar increase in dry matter production of sunflower due to application of pre-sowing seed treatment with GA has also been reported by [47]-[49] on sunflower and [40] [50] on other crops. The enhancement in CA activity and NR activity at both stages is greater at $10^{-5} \mathrm{M}$ GA over control is a worth mentioning fact. The enzyme CA which catalyses the reversible hydration of $\mathrm{CO}_{2}$ to bicarbonate and maintains its constant supply to Rubisco case at the level of the grana of the chloroplast [51]-[55]. Moreover, CA is also known to be involved in diverse physiological processes such as photosynthetic electron transport [56], and in maintain chloroplast $\mathrm{pH}$ during rapid changes in light intensity, ion-exchange, acid-base balance, carbohydrate/decarboxylation reactions and inor- 
ganic carbon diffusion between cell and its environment as well as inside the cell [57].

Furthermore, the enhancing effect of GA on CA activity and NR activity may be attributed to the hormone induced increase in transcription and/or translation of the genes that code for CA [58]. This may also be attributed, as for growth characters, to its (GA) roles, on one hand, and compensation of the "hidden hunger" for GA by its pre-sowing seed treatment or foliar application on the other. These results corroborate the various other findings [59] [60] on sunflower and [61] [62] on other plant. The improvement in leaf N, P and K contents at both stages (50 and 70 DAS) resulting from pre-sowing seed treatment with GA particularly at $10^{-3} \mathrm{M}$ GA over the control is not far to seek. These findings are in accordance with the results [20] [24] [26].

Moreover, GA treatment enhancing the permeability of the membranes and absorption of nutrients which enhanced the vegetative growth and development of more seeds [21] [34], and also due to existence of the imperative associators nutrients and biomass production [7]. It is a well-documented that a higher portion of leaf $\mathrm{N}$ is found in the chloroplast, most of it is invested in Rubisco alone, a key enzyme responsible for fixation of $\mathrm{CO}_{2}$ during the photosynthesis. Moreover, plants cultivated from GA-treated seeds (seed priming effect) exhibited higher exchange rate of $\mathrm{H}_{2} \mathrm{O} / \mathrm{CO}_{2}$ through stomata. Wang et al. [13] suggested that this exchange rate of $\mathrm{CO}_{2} / \mathrm{H}_{2} \mathrm{O}$ may be controlled by mesophyll function. Therefore, a low hindrance against this $\mathrm{CO}_{2} / \mathrm{H}_{2} \mathrm{O}$ exchange rate, in turn, facilitates a free exchange of gases and a grater exchange rate for $\mathrm{H}_{2} \mathrm{O}$ and $\mathrm{CO}_{2}$ through stomatal pore. Further, the cumulative effect of increased CA and NR activities could have enhanced the availability of $\mathrm{CO}_{2}$ under a more efficient exchange of $\mathrm{CO}_{2} / \mathrm{H}_{2} \mathrm{O}$ along with its rate of reduction by Rubisco. The abortion of flowers and seeds is one of the important determining factors of plant productivity. Vegetative growth of a crop and physico-biochemical processes control the number and size of photosynthesizing sites are responsible for production of photosynthates (sucrose) even after flowering and their partitioning ultimately controls yield characteristics [7] [18] [23]. Now, needless to explain, efficient interaction of all these basic determinants, coupled with GA-generated increase in the cyclic and non-cyclic [9], culminated in an increased rate of photosynthesis. Usually, GA is considered a promoter of photosynthesis and such results have also been reported by [34]. The increase in rate of photosynthesis implies more vegetative growth due to ample availability of nutrients. This, in turn, increases the size of the reproductive sink to attract more photo-assimilates and presumably results in greater potential for translocation of assimilates from the vegetative structures to pods. Sufficient availability of the assimilates subsequently leads to enhanced seed filling and culminates in increased seed yield, Table 11.

Increase in seeds per head suggesting the pre-sowing seed treatment of GA promotes differentiation leading to enhanced numbers of flowers, coupled with desirable development of under-developed seeds that result in stimulation of head-diameter, seeds per head and seed yield of treated plants, Table 11. It may also be added that application of GA promotes differentiation leading to enhanced number of flowers [8] [23] [56]. Its treatment may also be helpful in the desirable development of under-developed seeds particularly at the centre of the head as GA also causes cell division and cell enlargement [18]. These roles of GA directly or indirectly may be responsible for an increase in number of flowers coupled with the desirable development of under-developed seeds that result in higher values for head diameter and seeds per head of treated plants, Table 10.

Also, its promoting effect on $P_{N}$, membrane permeability and transport of photosynthates may be helpful in favouring the partitioning of photosynthates towards developing seeds in the head, hence higher value for other yield related characters of treated plants. Thus, the higher values for vegetative, physio-biochemical and yield characters of treated plants may culminate in higher seed yield, Table 11. This proposition is further confirmed by correlation studies wherein seed yield has shown positive relationship with the various parameters studied, for example, at 50 and 70 DAS respectively, dry weight ( $r=0.970$ and 0.990$)$, CA activity $(r=0.943$ and 1.000), NR activity ( $r=0.991$ and 0.980$)$, leaf $\mathrm{N}$ content $(r=0.884$ and 0.809$)$, leaf $\mathrm{P}$ content $(r=0.921$ and 0.872 ) and leaf $K$ content ( $r=0.992$ and 0.921 ) and at harvest, seeds per head $(r=0.982)$. These results are also in accordance with the findings of [43] [60].

The increase in the above yield attributes may be traced to its various roles mentioned earlier leading to observed higher values for growth characters and, physiological and biochemical parameters of treated plants. Moreover, it mediates differentiation [21] [40] leading to enhanced number of flowers which develop into heads. As mentioned earlier, it plays role in cell division and cell enlargement [8] [16] [17] [21] resulting in proper development of under-developed seeds in heads, hence higher values for seed yield per plant weight of treated plants; $P_{N}$ [20] supplying sufficient C skeleton; and membrane permeability [19] and transport of photosynthates [22] [32] favouring partitioning, hence, higher values for the yield parameters of treated plants. Thus, higher values for growth, physio-biochemical and yield characteristics of treated plants may culminate in higher seed 
yield.

\subsection{Effect of Seed-Priming Duration}

The observed enhancement in the values for most of the growth characters, physiological and biochemical parameters and yield and quality characteristics at the various growth stages resulting from pre-sowing seed treatment for $8 \mathrm{~h}$ over $4 \mathrm{~h}$ is noteworthy. It may be added here that a specific concentration of a phytohormone like other metabolites is required for optimum performance of a plant. Pre-sowing seed treatment with GA for $4 \mathrm{~h}$ may not be sufficient for accumulation of the hormone inside the seeds at the specific level as the seed coat of sunflower is thick and hard. The specific level of the hormone might have been achieved by soaking the seeds for $8 \mathrm{~h}$, hence higher values for most parameters studied. These results corroborate with the finding [40] [60] who also reported the effect of pre-soaking duration on the performance of brassica, black cumin and chickpea respectively.

\section{Conclusion}

The present study revealed that soaking of seeds in GA was more effective than the water soaked control for most of the parameters studied. The optimum concentration obtained for soaking the seeds in GA was $10^{-5} \mathrm{M}$. Duration of pre-soaking seed treatment with GA was also observed to be effective. Soaking the seeds in GA for $8 \mathrm{~h}$ was found to be optimum. Finally, it may be concluded that soaking the seeds with $10^{-5} \mathrm{M}$ GA for $8 \mathrm{~h}$ is best for growth and development of sunflower cv. PAC 3776.

\section{Acknowledgements}

We are grateful to Professor L.N. Sharma and Associate Professor Dr. Khalil Khan for his critical comments and valuable suggestions with regard to the preparation of the manuscript.

\section{References}

[1] K1aiyarasan, C. and Vaiyapuri, V. (2007) Effect of Integrated Nutrient Management Practices on Growth and Yield Attributes and Quality Characters of Sunflower (Helianthus L.). International Journal of Tropical Agricultural, 35, 15-18.

[2] Anonymous (1971) Urea: Foliar Spray on Crops in India. Japan Urea Centre, New Delhi.

[3] Russell, E.J. (1950) Soil Conditions and Plant Growth. 8th Edition, Longmans Green and Co., New York.

[4] Eriksen, J. and Askegaard, M. (2000) Sulphate Leaching in an Organic Crop Rotation on Sandy Soil in Denmark. Agriculture, Ecosystem and Environment, 78, 107-114. http://dx.doi.org/10.1016/S0167-8809(99)00117-6

[5] Suphiya, K., Vaishali and Vinay, S. (2010) Genetic Differentiation and Diversity Analysis of Medicinal Tree Syzygiumcumini (Myrtaceae) from Ecologically Different Regions of India. Physiology and Molecular Biology of Plants, 16, 1-10.

[6] Mazid, M. (2014) Response of Cicerarietinum L. to Plant Growth Regulators and Mineral Nutrients. Ph.D. Thesis, AMU, India.

[7] Gana, A.S. (2010) The Role of Synthetic Growth Hormones in Crop Multiplication and Improvement. African Journal of Biotechnology, 10, 10330-10334.

[8] Buchanan, B.B., Gruissen, W. and Jones, R.L. (2000) Biochemistry and Molecular Biology of Plants. American Society of Plant Physiologists, Rockville.

[9] Tiwari, D.K., Pandey, P, Giri, S.P. and Dwivedi, J.L. (2011) Effect of GA 3 and Other Plant Growth Regulators on Hybrid Rice Seed Production. Asian Journal of Plant Science, 10, 133-139. http://dx.doi.org/10.3923/ajps.2011.133.139

[10] Mazid, M. (2014) Seed Priming Application of Gibberellic Acid on Growth, Biochemical, Yield and Protein Status of Chickpea (Cicerarietinum L. cv. DCP 92-3). International Journal of Genetic Engineering and Biotechnology, 5, 17-22.

[11] Mazid, M. (2014) Application of Spray and Seed Priming GA 3 with P and S Ameliorate Seed Protein Content by Augmenting Photosynthetic Attributes, Enzymes Activities and Leghemoglobin Content of Chickpea. International Journal of Basic and Applied Biology, 1, 14-19.

[12] Khan, T.A., Mazid, M. and Quddusi, S. (2014) Role of Organic and Inorganic Chemicals in Plant-Stress Mitigation. In: Gaur, P.K. and Sharma, P., Eds., Approaches to Plant Stress and Their Management, Springer, India, 39-52. 
http://dx.doi.org/10.1007/978-81-322-1620-9_3

[13] Mazid, M. and Mohammad, F. (2012) Environmental Constraints Responsible for Reduction in Productivity of Chickpea: Revisit an Old Problem. International Journal of Environmental Engineering and Management, 3, 32-36.

[14] Yuan, L. and Xu, D.Q. (2001) Stimulation Effect of Gibberellic Acid Short-Term Treatment on Leaf Photosynthesis Related to the Increase in Rubisco Content in Broad Bean and Soybean. Photosynthesis Research, 68, 39-47. http://dx.doi.org/10.1023/A:1011894912421

[15] Khan, T.A., Mazid, M. and Mohammad, F. (2011) Climate Change, Sustainable Agriculture and Future Needs: A Perspective of Parallel Rethinking. Journal of Industrial Research and Technology, 1, 1-5.

[16] Marschner, H. (2002) Mineral Nutrition of Higher Plants. 2nd Edition, Academic Press, London.

[17] Taiz, L. and Zeiger, E. (2010) Plant Physiology. 5th Edition, Sinauer Associates, Inc., Sunderland.

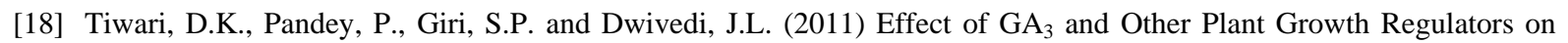
Hybrid Rice Seed Production. Asian Journal of Plant Sciences, 10, 133-139. http://dx.doi.org/10.3923/ajps.2011.133.139

[19] Wood, A. and Paleg, L.G. (1974) Alteration of Liposomal Membrane Fluidity by Gibberellic Acid. Australian Journal of Plant Physiology, 1, 31-40. http://dx.doi.org/10.1071/PP9740031

[20] Mazid, M. and Naqvi, N. (2014) Key Approaches of Plant Growth Regulator Application in Searching of Best Time for Enhancing Nitrogen Fixation Capacity of Chickpea Cultivar DCP 92-3. Unique Journal of Ayurvedic and Herbal Medicines, 2, 8-18.

[21] Huttly, A.K. and Phillips, A.L. (1995) Gibberellin-Regulated Plant Genes. Physiologia Plantarum, 95, 310-317. http://dx.doi.org/10.1111/j.1399-3054.1995.tb00843.X

[22] Estruch, J.J., Pereto, J.G., Vercher, Y. and Beltran, J.P. (1989) Sucrose Loading in Isolated Veins of Pisum sativum: Regulation by Abscisic Acid, Gibberellic Acid and Cell Turgor. Plant Physiology, 91, 259-265. http://dx.doi.org/10.1104/pp.91.1.259

[23] Mazid, M. and Naqvi, N. (2014) Differential Yield and Quality Response of Four Chickpea Cultivars Following the Foliar Spray of Five Selected Plant Growth Regulators. Agricultural Science Digest, 34, 268-272. http://dx.doi.org/10.5958/0976-0547.2014.01017.9

[24] Ouzounidou, G. and Ilias, I. (2005) Hormone-Induced Protection of Sunflower Photosynthetic Apparatus against Copper Toxicity. Biologia Plantarum, 49, 223-228. http://dx.doi.org/10.1007/s10535-005-3228-y

[25] Watson, D.J. (1958) The Dependence of Net Assimilation Rate on Leaf Area Index. Annals of Botany, 22, 37-54.

[26] Dwivedi, R.S. and Randhawa, N.S. (1974) Evaluation of a Rapid Test for the Hidden Hunger of Zinc in Plants. Plant and Soil, 40, 445-451. http://dx.doi.org/10.1007/BF00011531

[27] Jaworski, E.G. (1971) Nitrate Reductase Assay in Intact Plant Tissues. Biochemical and Biophysical Research Communications, 43, 1274-1279. http://dx.doi.org/10.1016/S0006-291X(71)80010-4

[28] Lindner, R.C. (1944) Rapid Analytical Methods for Some of the More Common Inorganic Constituents of Plant Tissues. Plant Physiology, 19, 76-89. http://dx.doi.org/10.1104/pp.19.1.76

[29] Fiske, C.H. and Subbarow, Y. (1925) The Colorimetric Determination of Phosphorus. Journal of Biological Chemistry, 66, 375-400.

[30] Anonymous (1970) Pharmacopoeia of India. 2nd Edition, Manager of Publications, Ministry of Health, Government of India, New Delhi, 947-948.

[31] Gomez, K.A. and Gomez, A.A. (1984) Statistical Procedures for Agricultural Research. 2nd Edition, John Wiley and Sons, New York.

[32] Badger, M.R. and Price, G.D. (1994) The Role of Carbonic Anhydrase in Photosynthesis. Annual Review of Plant Physiology and Plant Molecular Biology, 45, 369-392. http://dx.doi.org/10.1146/annurev.pp.45.060194.002101

[33] Mazid, M., Ali, B., Hayat, S. and Ahmad, A. (2010) The Effect of 4-Chloro-3-indoleacetic Acid on Some Growth Parameters in Mung Bean under Cadmium Stress. Turkish Journal of Biology, 34, 9-13.

[34] Arteca, R.N. and Dong, C.N. (1981) Stimulation of Photosynthesis by Application of Phyto-Hormones to the Root Systems of Tomato Plants. Photosynthesis Research, 2, 243-249. http://dx.doi.org/10.1007/BF00056261

[35] Campbell, W.H. (1999) Nitrate Reductase Structure, Function and Regulation: Bridging the Gap between Biochemistry and Physiology. Annual Review of Plant Physiology and Plant Molecular Biology, 50, 277-303. http://dx.doi.org/10.1146/annurev.arplant.50.1.277

[36] Okabe, K., Angela, L., Mikio, T. and Shigetoh, M. (1980) Effect of Carbonic Anhydrase on Ribulose 1, 5-Biphosphate Carboxylase and Oxygenase. FEBS Letters, 114, 142-144. http://dx.doi.org/10.1016/0014-5793(80)80879-9

[37] Mazid, M. and Roychowdhury, R. (2014) Leaf N-P-K Content as Indicators of Yield, Total Protein and Sugar Content 
of Seeds of Bengal Gram (Cicer arietinum L.). Unique Journal of Pharmaceutical and Biological Sciences, 2, 21-31.

[38] Clouse, S.D. and Sasse, J.M. (1998) Brassinosteroids: Essential Regulators of Plant Growth and Development. Annual Review of Plant Physiology and Plant Molecular Biology, 49, 427-451. http://dx.doi.org/10.1146/annurev.arplant.49.1.427

[39] Saran, B., Sinha, B.K., Sharma, A.K. and Mehta, A.S. (1992) Effect of Pre-Sowing Seed Treatment in GA 3 on Growth, Yield and Chlorophyll in Mustard. New Agriculture, 3, 59-60.

[40] Thakare, U., Patil, N. and Malpathak, N. (2011) Performance of Chickpea under the Influence of Gibberellic Acid and Oxygenated Peptone during Germination. Advances in Bioscience and Biotechnology, 2, 40-45. http://dx.doi.org/10.4236/abb.2011.21007

[41] Mazid, M., Roy Chowdhury, R. and Khan, F. (2014) Evaluation of Chickpea Cultivation Approaches in Terms of Environmental Resilience and Future Protein Security. Current Agriculture Research Journal, 2, 164-174.

[42] Mazid, M., Khan, T.A., Mohammad, F. and Nooris, N. (2013) Physico-Biochemical Effects of Pre-Sowing Seed Treatment with Gibberellic Acid on Helianthus annus L. National Conference of Plant Physiology, Current Trends in Plant Biology Research, Junagarh, 13-16 December 2013, 895-896.

[43] Iqbal, H.F., Tahir, A., Khalid, M.N., I-ul-Haq and Ahmad, A.N. (2001) Response of Chickpea (Cicer arietinum L.) Growth towards the Foliar Application of Gibberellic Acid at Different Growth Stages. Pakistan Journal of Biological Sciences, 4, 433-434. http://dx.doi.org/10.3923/pjbs.2001.433.434

[44] Yadav, R.M. and Bharud, R.W. (2006) Response of Kabuli Chickpea to the Foliar Application of Growth Substances. Mysore Journal of Agricultural Sciences, 40, 134-137.

[45] Mazid, M., Khan, T.A. and Mohammad, F. (2011) Potential Role of NO and $\mathrm{H}_{2} \mathrm{O}_{2}$ as Signalling Molecules in Tolerance to Abiotic Stress in Plants. Journal of Industrial Research and Technology, 1, 56-68.

[46] Hassanpourdagham, M.B., El-Amery, E.M. and Mazid, M. (2015) Note on the Enzyme Activities, Productivity and Quality Parameters of Chickpea Cultivars under Influence of Diverse Synthetic Plant Growth Promoters. Post Harvest Science and Technology, 2, 23-38.

[47] Mazid, M. and Khan, T.A. (2014) Molecules, Enzymes and Plant Productivity. APH Publishing Corporation Pvt. Ltd., Daryaganj.

[48] Khan, T.A., Mazid, M., Ansari, S.A., Azam, A. and Naeem, A. (2012) Zinc Oxide Nanoparticles Promote the Aggregation of Conconavalin A. International Journal of Peptide Research and Therapeutics, 3, 23-27.

[49] Mazid, M. and Khan, F. (2015) Analysis of Response of Chick-Pea Cultivars to Various Insecticides-A Pot Evaluation. Conceptual Framework and Innovations in Agro-Ecology and Food Sciences, 1, 68-72.

[50] Naqvi, N., Khan, T.A., Mazid, M., Khan, F., Quddusi, S. and Roychowdhury, R. (2014) Phytoremediatory Potential of Guava and Ashok Tree at Three Different Sites of Bareilly District-A Case Study. ARPN Journal of Agricultural and Biological Science, 9, 101-109.

[51] Majeau, N. and Coleman, J.R. (1994) Correlation of Carbonic Anhydrase and Ribulose-1,5-biphosphate Carboxylase/ Oxygenase Expression in Pea. Plant Physiology, 104, 1393-1399.

[52] Price, A.H., Taylor, A., Ripley, S.J., Griffiths, A., Trewavas, A.J. and Knight, M.R. (1994) Oxidative Signals in Tobacco Increase Cytosolic Calcium. Plant Cell, 6, 1301-1310. http://dx.doi.org/10.1105/tpc.6.9.1301

[53] Jain, V., Khetarpal, S., Das, R. and Abrol, Y.P. (2011) Nitrate Assimilation in Contrasting Wheat Genotypes. Physiology and Molecular Biology of Plants, 17, 137-144. http://dx.doi.org/10.1007/s12298-011-0061-y

[54] Mazid, M., Khan, T.A. and Mohammad, F. (2012) Role of Nitrate Reductase in Nitrogen Fixation under Photosynthetic Regulation. World Journal of Pharmaceutical Research, 1, 386-414.

[55] Hassanpouraghdam, M.B., Hajisamadi, A.B. and Khalighi, A. (2011) Gibberellic Acid Foliar Application Influences Growth, Volatile Oil and Some Physiological Characteristics of Lavender (Lavandula officinalis Chaix). Romanian Biotechnological Letters, 16, 6322-6327.

[56] Stemler, A.J. (1997) The Case for Chloroplast Thylakoid Carbonic Anhydrase. Physiologia Plantarum, 99, $348-353$. http://dx.doi.org/10.1111/j.1399-3054.1997.tb05423.x

[57] Hopkins, W.G. (2004) Introduction to Plant Physiology. 2nd Edition, John Wiley and Sons, Inc., Hoboken.

[58] Sugiharto, B., Burnell, J.N. and Sugiyama, T. (1992) Cytokinin Is Required to Induce the Nitrogen Dependent Accumulation of mRNAs for Phosphoenol Pyruvate Carboxylase and Carbonic Anhydrase in Detached Maize Leaves. Plant Physiology, 100, 153-156. http://dx.doi.org/10.1104/pp.100.1.153

[59] Chanda, S.V., Sood, C.R., Reddy, V.S. and Singh, Y.D. (1998) Influence of Plant Growth Regulators on Some Enzymes of Nitrogen Assimilation in Mustard Seedling. Journal of Plant Nutrition, 21, 1765-1777. http://dx.doi.org/10.1080/01904169809365521 
[60] Aloni, B., Daie, J. and Wyse, R.E. (1986) Enhancement of $\left({ }^{14} \mathrm{C}\right)$-Sucrose Export from Source Leaves of Vicia faba by Gibberellic Acid. Plant Physiology, 82, 962-966. http://dx.doi.org/10.1104/pp.82.4.962

[61] Indurker, S., Misra, H.S. and Eapen, S. (2010) Agrobacterium-Mediated Transformation in Chickpea (Cicer arietinum L.) with an Insecticidal Protein Gene: Optimisation of Different Factors. Physiology and Molecular Biology of Plants, 16, 273-284. http://dx.doi.org/10.1007/s12298-010-0030-X

[62] Praveen, K.S., Sharma, S.K. and Choi, I.Y. (2010) Individual and Combined Effects of Water-Logging and Alkalinity on Yield of Wheat (Triticum aestivum L.) Imposed at Three Critical Stages. Physiology and Molecular Biology of Plants, 16, 317-320. http://dx.doi.org/10.1007/s12298-010-0027-5 